\title{
THE USE OF ANTIFIBRINOLYTICS IN HIP TRAUMA SURGERY IN A PUBLIC HEALTH SYSTEM: A PROSPECTIVE STUDY
}

\author{
O USO DE ANTIFIBRINOLÍTICOS EM CIRURGIA \\ DE TRAUMA DE QUADRIL EM UM SERVIÇO \\ PÚBLICO DE SÁUDE: ESTUDO PROSPECTIVO
}

\author{
José Alberto alves Oliveira ${ }^{1}$ (i), Gabriella Cristina Coelho de Brito ${ }^{2,3}$ (i), Francisca Magna Prado BezerRa 3,4 (1), \\ Carlos Alfredo de Carvalho Neto ${ }^{4,5}$ (i), Jonatas Brito de Alencar Neto $0^{5,6}$ (i), Roberto César Pontes Ibiapina ${ }^{3,4}$ (i) \\ 1. Universidade Federal do Ceará, Fortaleza, Ceará, Brazil. \\ 2. Hospital Infantil Albert Sabin, Fortaleza, Ceará, Brazil. \\ 3. Hospital Geral de Fortaleza, Serviço de Ortopedia/Traumatologia, Fortaleza, Ceará, Brazil. \\ 4. Instituto Dr. José Frota, Serviço de Anestesiologia, Fortaleza, Ceará, Brazil. \\ 5. Hospital da Restauração Governador Paulo Guerra, Recife, PE, Brazil. \\ 6. Instituto Dr. José Frota, Serviço de Traumatologia, Fortaleza, Ceará, Brazil.
}

\section{ABSTRACT}

Objective: To evaluate the use of tranexamic acid (TXA) and $\varepsilon$-aminocaproic acid (EACA) in reducing blood loss in hip and proximal femur trauma surgery. Methods: Prospective study with 49 patients surgically treated in a trauma hospital between Nov/2015 and Feb/2017. The patients were divided in two groups: TXA $(n=24)$ and EACA $(n=25)$. The comparison was made according to gender, age at the time of surgery, ASA, fracture and surgery type, estimated blood loss during surgical approach, hemoglobin and hematocrit levels pre and post-operative, and pharmacological cost. The data was processed using SPSS 22.0 with significance level of $p<0,05$. Results: No significant difference was found in the variables age, gender, ASA and estimated blood loss during surgical approach. No patient needed blood transfusion. When evaluated post-operatively, the hemoglobin and hematocrit values decrease had no significant difference between the antifibrinolytics ( $p>0.05$ ). When analyzing total cost for both pharmacological agents, higher cost was observed in EACA than in TXA (US\$16.09 - US\$2.73), resulting in a US\$13.36 addition per patient. Conclusion: Antifibrinolytic use was efficient on lowering the total blood loss, without the need of blood transfusion. Level of evidence II, Prospective Comparative Study.

Keywords: Anti-Fibrinolytic. Hip Fractures. Surgery.

\section{RESUMO}

Objetivo: Avaliar o uso do ácido tranexâmico (ATX) e aminocapróico (AEAC) na redução da perda sanguínea em cirurgias para trauma do quadril e femur proximal. Métodos: Estudo prospectivo com 49 pacientes operados em hospital de trauma entre nov./15 e fev./17. Pacientes divididos em dois grupos: ATX $(n=24)$ e AEAC $(n=25)$. Comparações feitas de acordo com o sexo, idade na cirurgia, ASA, tipo de fratura e cirurgia, perda sanguínea estimada durante a cirurgia, níveis de hemoglobina e hematócrito pré e pós-operatório e o custo das medicações. Dados processados no SPSS $22.0 \mathrm{com}$ nível de significância de $p<0,05$. Resultados: Não foram encontradas diferenças significativas entre as seguintes variáveis: idade, sexo, ASA e perda sanguínea estimada durante a cirurgia. Nenhum paciente necessitou de transfusão sanguínea nos dois grupos. Na avaliação pós-operatória, não houve diferença significativa entre os grupos nos valores de queda da hemoglobina e hematócrito $(p>0,05)$. Analisando os custos de ambos as medicações, observou-se um custo mais elevado do AEAC em relação ao ATX (R\$90,00 - $R \$ 15)$, resultando em $R \$ 75,00$ a mais por paciente. Conclusão: O uso dos antifibrinolíticos foi eficiente na redução da perda sanguínea, sem a necessidade de hemotransfusões. Nível de evidência II, Estudo Prospectivo Comparativo.

Descritores: Antifibrinolíticos. Fraturas de Quadril. Cirurgia.

Citation: Oliveira JAA, Brito GCC, Bezerra FMP, Carvalho CA Neto, Alencar JB Neto, Ibiapina RCP. Antifibrinolytics use in hip trauma surgery in a public health system: a prospective study. Acta Ortop Bras. [online]. 2021;29(6):304-307. Available from URL: http://www.scielo.br/aob.

\section{INTRODUCTION}

Blood loss is one of the main complications in major trauma surgeries, and, depending on how much is lost, it needs to be treated with transfusion, under the risk of immune and non-immune adverse reactions. ${ }^{1-3}$

Aiming to reduce the need for transfusion in surgeries with high blood loss, several techniques for blood management are used,

All authors declare no potential conflict of interest related to this article.

The study was conducted at Instituto Dr. José Frota.

Correspondence: José Alberto Alves Oliveira. Rua Bruno Porto, 600, apto. 2201-A, Fortaleza, CE, Brazil, 60824010. bertoalvesoliveira@gmail.com 
being the administration of antifibrinolytics one of them. The usage of tranexamic acid (TXA), and $\varepsilon$-aminocaproic acid (EACA) antagonize fibrinolytic activity, and therefore reduce the amount of lost blood. ${ }^{4-7}$ Studies have been demonstrating that the use of these medications in patients who had undergone orthopedic surgery, has led to a significant reduction in the total blood loss, without the increase of thromboembolic events. ${ }^{6,8}$ However, research comparing the cost-effectiveness between these two drugs are limited in hip trauma surgery.

This study intents to evaluate the use of tranexamic acid and $\varepsilon$-aminocaproic acid in reducing blood loss in hip and proximal femur trauma surgery.

This study was approved by the Ethics in Research Committee of the aforementioned institution with the statement number 1.539.629.

\section{MATERIAL AND METHODS}

Prospective cohort study with a sample of 49 patients that underwent hip and/or proximal femur surgery, at a single metropolitan level 1 regional trauma center between November 2015 and February 2017.

Exclusion criteria were refusing participate, and the ones who presented renal insufficiency, allergies to TXA and/or EACA, or had a history of hemostasis disorders, low blood platelet count $(<100,000)$, altered prothrombin time (PT)/international normalized ratio (INR), activated partial thromboplastin time (APTT); thromboembolic events before the surgery, or family history of thromboembolism; ASA (American Society of Anesthesiologists) score $>3$, infection at the puncture point of the subarachnoid block, blood in urine, clinical signs of acute hypovolemia, and pregnant or lactating women.

No patient has made use of previously donated autologous blood, isovolemic hemodilution in the intraoperative stage, intraoperative blood salvage, and erythropoietin (EPO) during the pre and postsurgical stages.

The sample was chosen by convenience, and the patients were divided into two groups, the first one was the tranexamic acid group (TXA) and the second was the $\varepsilon$-aminocaproic acid group (EACA). The TXA group had $1 \mathrm{~g}$ of tranexamic acid administered, and the EACA group was medicated with $4 \mathrm{~g}$ of $\varepsilon$-aminocaproic acid, both diluted in $100 \mathrm{ml}$ of saline solution $0.9 \%$ received via intravenous infusion at the beginning of the surgery, right after the neuro-axis blockage, with no maintenance dose.

There was no blinding in the study, therefore the surgical team had knowledge of the administered medication. The team had four orthopedic trauma surgeons, with expertise in hip surgery, and two anesthesiologists.

For hip surgery, patients were placed onto the operating table on lateral decubitus position for the Kocher Langenbeck approach, whereas for the proximal femur surgery they were placed on dorsal decubitus position. For the acetabular approach, they were positioned either in dorsal decubitus or lateral decubitus, depending on the acetabular wall/column that was affected. Proximal femur conformation and the cortical index, as described by Dorr et al., ${ }^{9}$ was employed in the total arthroplasty of the hip $(A, B, C)$ for the femoral component cementation, or not.

The parameters for blood transfusion included hemoglobin below $7 \mathrm{~g} / \mathrm{dl}$ in the gasometry analysis, or hemoglobin below $8 \mathrm{~g} / \mathrm{dl}$ with signs and symptoms of anemia: tachycardia (> $100 \mathrm{bpm}$ ) and hypotension ( $<100 \mathrm{mmHg}$ of systolic blood pressure) refractory to volume expansion. Both the surgeon and the anesthetist made a cooperative decision for the blood transfusion during the surgery. The patients underwent deep vein thrombosis and pulmonary embolism prophylaxis with low molecular weight heparin (enoxaparin), $40 \mathrm{mg} /$ day, subcutaneously, initiated in the hospital admission, suspended 12 hours before the procedure and reinitiated 12 hours after surgery until hospital discharge. Subsequently, the patients had a prescription of an oral Xa inhibitor factor, used during 21 days after osteosynthesis and 30 days after hip arthroplasty.

The blood loss was quantified by counting and weighing the medical dressings used during, before and after the surgery, as well as counting all the amount of saline solution and other liquids during the intraoperative stage of the surgery - used for basal patient hydration. The weight of the medical dressings after the surgery was subtracted from their original weight, and the result provided an estimated blood loss for the intraoperative stage. The conversion of the weight difference between the medical dressings used before and after the surgery considered the blood density of $1.05 \mathrm{~g} / \mathrm{ml}$. The suction drain was not used during the post-surgical stage.

The groups were compared according to the following data on their medical history; gender; age at the time of the surgery; ASA Score (I, II, or III); intraoperative volume of blood loss and pre and postsurgical levels of hemoglobin $(\mathrm{Hb})$, hematocrit $(\mathrm{Ht})$. The cost of medication used per patient in the surgery was described.

The patients were followed up during surgery and six months post-operatively for possible adverse reactions to the medication, such as conjunctivitis, diarrhea, urticaria, headache, nausea, vomiting, delirium, convulsive crises, hypotension, arterial fibrillation, renal failure and thromboembolic events.

Data was processed at the SPSS 22.0, license number 10101131007, when the average, medium and standard-deviation measures were estimated. The general characteristics of TXA and EACA groups were compared with Qui-Square and Fisher Exact Tests, whereas the average measures of the hematimetric levels $(\mathrm{Hb}$ and $\mathrm{Ht}$ ) were compared in accordance with the Tukey test. Trust level was set as 0.05 .

\section{RESULTS}

From 60 patients, 11 were excluded, the others were divided into two groups: TXA (24 patients) and EACA (25 patients). For the acetabular fractures, the first group (TXA) had a double approach (anterior + posterior) for two patients, anterior for one patient and posterior for another; in the second group posterior approach was performed in three patients and ilioinguinal approach in one patient. For the femoral neck fractures, the EACA group had 4 patients subjected to posterolateral approach and one to lateral approach, whereas, in the TXA group, the approaches were performed, respectively, in ten and one patients. When mentioning the transtrochanteric fractures (15 in EACA and 8 in TXA), all had lateral approach. The EACA group had one subtrochanteric fracture resolved by lateral approach, and the TXA group had a pelvic ring (pubic symphyses) approached previously.

The average age ranged from $68.38 \pm 18.92$ years old in the TXA group and $67.85 \pm 22.13$ years old in the EACA group $(p>0.05)$. No significant difference was observed between the groups regarding the variables gender, the ASA scores $\mathrm{I} / \mathrm{II} / \mathrm{III}$, or by quantifying the perioperative blood loss of the studied subjects (Table 1). 
Table 1. Comparison of clinical and surgical characteristics among the groups.

\begin{tabular}{|c|c|c|c|}
\hline & TXA (N = 24) & EACA (N = 25) & $\mathbf{P}$ \\
\hline Age (years) & $\begin{array}{ll}68.38 & 18.92 \\
\end{array}$ & $67.85 \quad 22.13$ & $0.180^{1}$ \\
\hline Gender & & & $0.740^{1}$ \\
\hline Male & $21(34.42 \%)$ & $19(31.16 \%)$ & \\
\hline Female & $5(29.41 \%)$ & $7(41.17 \%)$ & \\
\hline ASA & & & $0.300^{2}$ \\
\hline 1 & 6 & 6 & \\
\hline$\|$ & 14 & 12 & \\
\hline III & 4 & 7 & \\
\hline \multicolumn{4}{|l|}{$\begin{array}{c}\text { FRACTURES } \\
\text { (AO Classification) }\end{array}$} \\
\hline $31 \mathrm{~A} 1$ & 2 & 5 & \\
\hline $31 \mathrm{~A} 2$ & 7 & 10 & \\
\hline 31B2 & 5 & 4 & \\
\hline 31B3 & 4 & 1 & \\
\hline $32 \mathrm{~A} 1$ & 1 & - & \\
\hline $32 \mathrm{~B} 1$ & - & 1 & \\
\hline $61 \mathrm{~B} 1$ & 1 & - & \\
\hline $62 \mathrm{~A} 1$ & 1 & 1 & \\
\hline $62 \mathrm{A3}$ & 1 & 1 & \\
\hline $62 \mathrm{C} 2$ & 2 & 2 & \\
\hline \multicolumn{4}{|l|}{ SURGERY } \\
\hline \multicolumn{4}{|l|}{ Acetabulum } \\
\hline Plate + Screw & 4 & 4 & \\
\hline \multicolumn{4}{|l|}{ Femoral neck } \\
\hline Canulated screws & 1 & 1 & \\
\hline $\begin{array}{l}\text { Non-cemented total } \\
\text { hip arthroplasty }\end{array}$ & 8 & 4 & \\
\hline Hemiarthroplasty & 2 & - & \\
\hline \multicolumn{4}{|l|}{ Transtrochanteric } \\
\hline DHS & 8 & 15 & \\
\hline \multicolumn{4}{|l|}{ Subtrochanteric } \\
\hline DCS & - & 1 & \\
\hline $\begin{array}{c}\text { Pubic Symphyses } \\
\text { Intraop. Blood Loss (ml) }\end{array}$ & $225.30 \quad 123.56$ & $241.65-102.42$ & $0.190^{1}$ \\
\hline
\end{tabular}

${ }^{1}$ Qui-Square Test; ${ }^{2}$ Fisher Exact Test.

TXA: Tranexamic Acid Group, EACA: $\mathcal{E}$-Aminocaproic Acid Group.

The hemoglobin values observed in the pre-surgical stage were similar in all studied groups. In the post-surgical stage, however, these values were higher in the TXA group compared to the EACA group, but the differences were not significant $(p>0.05)$ (Table 2$)$. When evaluating the percentage of hematocrit decrease, no differences between the TXA and EACA groups were observed ( $p>0.05$ ). We emphasize that there was no need for blood transfusion in either group.

Analyzing the cost of the medication, it was found that each patient spent approximately US\$16 with the aminocaproic acid, almost 5 times more than tranexamic acid (US\$2.73) (Table 3).

Table 2. Comparison of hemoglobin and hematocrit values during the pre and post-surgical stages between the groups.

\begin{tabular}{c|c|cc|cc|c}
\hline & \multicolumn{2}{|c|}{ TXA } & \multicolumn{2}{|c|}{ EACA } & $\mathbf{p}$ \\
\hline HEMOGLOBIN (g/dl) & & & & & & \\
\hline Pre-surgical & & 11.20 & 1.51 & 11.05 & 1.38 & 0.46 \\
\hline 1st post-surgical & & 10.36 & 1.39 & 9.87 & 1.06 & 0.39 \\
\hline Reduction & & 0.83 & 0.49 & 1.12 & 0.71 & 0.33 \\
\hline HEMATOCRIT (\%) & & & & & & \\
\hline Pre-surgical & & 33.16 & 4.49 & 33.10 & 3.92 & 0.99 \\
\hline 1st post-surgical & & 30.33 & 4.07 & 29.99 & 3.15 & 0.94 \\
\hline Reduction & & 2.93 & 2.01 & 3.26 & 2.04 & 0.87 \\
\hline
\end{tabular}

P by Tukey Test.

TXA: Tranexamic Acid Group, EACA: E-Aminocaproic Acid Group.
Table 3. Cost-effectiveness evaluation of tranexamic acid usage versus $\varepsilon$-aminocaproic acid

\begin{tabular}{c|c|c|c|c|c|c}
\hline & Presentation & Volume & $\begin{array}{c}\text { Value } \\
\text { (US\$) }\end{array}$ & $\begin{array}{c}\text { Vial/ } \\
\text { Patient }\end{array}$ & $\begin{array}{c}\text { Final Cost/ } \\
\text { Patient (US\$) }\end{array}$ & $\begin{array}{c}\text { Total Cost } \\
\text { (US\$) }\end{array}$ \\
\hline EACA & $50 \mathrm{mg} / \mathrm{ml}$ & $20 \mathrm{ml}$ & 4.02 & 4 & 16.09 & 418.30 \\
\hline TXA & $50 \mathrm{mg} / \mathrm{ml}$ & $5 \mathrm{ml}$ & 0.68 & 4 & 2.73 & 70.98 \\
\hline$\Delta$ & - & - & 3.34 & - & 13.36 & 347.32 \\
\hline
\end{tabular}

\section{DISCUSSION}

The perioperative stage in hip surgery involves an extensive tissue damage, the activation of the coagulation and fibrinolysis systems. In these cases, the use of antifibrinolytics is clearly beneficial to the reduction of perioperative blood loss and the demand for blood components, ${ }^{10}$ and, currently, TXA and EACA are the most used in clinical practice. ${ }^{11-13}$

Benoni and collaborators ${ }^{11}$ have shown that tranexamic acid had not significantly reduced the blood loss in the primary hip arthroplasty, despite more patients in the control group (26 vs 21) needing blood transfusion, such difference was not significant.

Yamasaki et al. ${ }^{12}$ elaborated a study with 40 patients that suffered from hip osteoarthritis and have undergone a non-cemented total hip arthroplasty. They were sorted randomly into two distinct groups: one used $1 \mathrm{~g}$ of tranexamic acid five minutes before the procedure, and the other that did not use the drug. The previously medicated group showed a significant reduction of blood loss than the other group which had not used any antifibrinolytic.

This study shows that reduction in hemoglobin and hematocrit was lower in the TXA group than by the EACA group, but the difference between them was not significant. These results are reinforced by other studies. ${ }^{7,13}$

Lee et al..$^{14}$ evaluated 270 patients who had undergone hip hemiarthroplasty surgery and concluded that the tranexamic acid is advantageous to the patient's health due to the lower intraoperative and post-surgical blood loss. Besides, according to them this advantage extends to cost-effectiveness, since the administration of TXA saves up to $£ 6,300$ yearly, per patient, with blood transfusions avoided by using this drug. Hobbs et al. ${ }^{15}$ conducted a study with patients that had undergone knee or hip, total arthroplasty. They had two different groups, one that used EACA and other that used TXA as antifibrinolytic. And, besides showing that this type of medication is beneficial to patients, they also observed that using them costs less for the public health system, since the price of blood transfusion is higher than the price of antifibrinolytics. ${ }^{15}$

In a meta-analysis study with polytraumatized patients, Pinto et al. ${ }^{16}$ concluded that the cost-effectiveness of tranexamic acid is $\$ 14.96$ per year lived. According to these authors, TXA is highly cost-effective, and should be used in protocol for polytrauma patients.

In this study, both antifibrinolytic agents used were beneficial. However, when comparing the total cost of these medication in both groups, a higher cost of $\$ 347.32$ was observed in the group using $\varepsilon$-aminocaproic acid. This difference shows a simple cost analysis in favor of using tranexamic acid.

Regarding unfavorable results, no adverse reactions with the $1 \mathrm{~g}$ TXA dose, and $4 \mathrm{~g}$ EACA dose, such as thromboembolic events, allergic reactions, or low renal function were observed during the trans-operative period, or even in 180 days after the surgery. These results were similar to revision studies previously carried out. ${ }^{8,10}$ Unfortunately, given the resource-limited setting in which this study was performed. The single-centered nature, lack of a control group and the small sample size may be the cause of bias. However, for the choice of treatments in public health system, the decisions need be based on the costs, benefits, and likelihoods of all potential consequences of treatments. 


\section{CONCLUSION}

Our study stated that the use of antifibrinolytics (tranexamic acid and $\varepsilon$-aminocaproic acid) is an effective procedure to lower the reduction of the hematimetric levels, since no significant difference was observed between the two drugs used, the one with the lowest cost can be chosen, which, in this study, was the tranexamic acid.

AUTHORS' CONTRIBUTIONS: Each author contributed individually and significantly to the development of this article. JAAO: writing, statistical analysis, intellectual concept, and preparation of the entire research project; GCCB: writing, review and intellectual concept; FMPB: writing, review, intellectual concept and surgeries; CACN: writing and review; JBAN: writing, review and surgeries; RCPI: writing, review and surgeries.

\section{REFERENCES}

1. Elawad AAR, Öhlin AK, Berntorp E, Nilsson IM, Fredin H. Intraoperative autotransfusion in primary hip arthroplasty: a randomized comparison with homologous blood. Acta Orthop Scand. 1991;62(6):557-62.

2. Bridgens JP, Evans CR, Dobson PMS, Hamer AJ. Intraoperative red blood-cell salvage in revision hip surgery a case-matched study. J Bone Joint Surg Am. 2007;89(2):270-5.

3. McMurray MR, Birnbaum MA, Walter NE. Intraoperative autologous transfusion in primary and revision total hip arthroplasty. J Arthroplasty. 1990;5(1):61-5.

4. Oliveira JAA, Façanha Filho FAM, Fernandes FV, Almeida PC, Oliveira VF, Verde SRL. Is cell salvage cost-effective in posterior arthrodesis for adolescent idiopathic scoliosis in the public health system? J Spine Surg. 2017;3(1):2-8.

5. Oliveira JAA, Façanha Filho FAM, Feijão SX, Fernandes FV, Almeida PC, Carlos LMB, Verde SRL. Influence of intraoperative blood salvage on surgery for scoliosis. Coluna/Columna. 2017;16(1):33-7.

6. Henry DA, Carless PA, Moxey AJ, O'Connell D, Stokes BJ, Fergusson DA, Ker K. Anti-fibrinolytic use for minimising perioperative allogeneic blood transfusion (review). Cochrane Database Syst Rev. 2011;19(1):CD001886.

7. Nunes NG, Oliveira JAA, Bezerra FMP, Nascimento VD, Dumaresq DMH, Patrocinio MCA. Is intraoperative blood cell salvage effective in hip surgery? Rev Bras Ortop. 2019;54:377-81.

8. Zufferey P, Merquiol F, Laporte S, Decousus H, Mismetti P, Auboyer C, et al. Do antifibrinolytics reduce allogeneic blood transfusion in orthopedic surgery? Anesthesiology. 2006;105:1034-46.
9. Dorr LD, Faugere MC, Mackel AM, Gruen TA, Bognar B, Malluche HH. Structural and cellular assessment of bone quality of proximal femur. Bone. 1993; 14:231-42.

10. Niskanen RO, Korkala OL. Tranexamic acid reduces blood loss in cemented hip arthroplasty: a randomized, double-blind study of 39 patients with osteoarthritis. Acta Orthop. 2005;76:829-32.

11. Benoni G, Lethagen S, Nilsson P, Fredin H. Tranexamic acid, given at the end of the operation, does not reduce postoperative blood loss in hip arthroplasty. Acta Orthop Scand. 2000;71:250-4.

12. Yamasaki S, Masuhara K, Fuji T. Tranexamic acid reduces blood loss after cementless total hip arthroplasty - prospective randomized study in 40 cases. Int Orthop. 2004;28:69-73.

13. Ekbäck G, Axelsson K, Ryttberg L, Edlund B, Kjellberg J, Weckström J. Tranexamic acid reduces blood loss in total hip replacement surgery. Anesth Analg. 2000;91:1124-30.

14. Lee C, Freeman R, Edmondson M, Rogers BA. The efficacy of tranexamic acid in hip hemiarthroplasty surgery: an observational cohort study. Injury. 2015;46(10):1978-82.

15. Hobbs JC, Welsby IJ, Green CL, Dhakal IB, Wellman SS. Epsilon aminocaproic acid to reduce blood loss and transfusion after total hip and total knee arthroplasty. J Arthroplasty. 2018;33:55-60.

16. Pinto MA, Silva JG, Chedid AD, Chedid MF. Uso de ácido tranexâmico no trauma: uma análise de custo-efetividade para o uso no Brasil. Arq Bras Cir Dig. 2016;29(4):282-6. 